\title{
New distribution records of Anairetes alpinus (Carriker, 1933) (Aves, Tyrannidae), a highly specialized and endangered bird of Polylepis forests in Junín, Peru
}

\author{
Harold Rusbelth Quispe-Melgar ${ }^{1}$, Wendy Carolay Navarro Romo ${ }^{1}$, Fressia Nathalie \\ Ames-Martínez ${ }^{1}$, Vladimir Fernando Camel Paucar ${ }^{1}$ and C. Steven Sevillano-Ríos ${ }^{2,3}$
}

1 Universidad Continental, Laboratorio de Biotecnología y Biología Molecular, Av. San Carlos 1980, urbanización San Antonio, Huancayo, Junín, Peru. 2 Cornell Lab of Ornithology, 159 Sapsucker Woods Rd., Ithaca, NY 14850, USA. 3 Department of Natural Resources, Cornell University, Fernow Hall, Ithaca, NY 14853, USA.

Corresponding author: Harold Rusbelth Quispe-Melgar, rusbeltharold@gmail.com

\begin{abstract}
The Ash-breasted Tit-tyrant, Anairetes alpinus (Carriker, 1933) (Aves, Tyrannidae), is an endangered and highly specialized bird that inhabits the Polylepis forests (Rosaceae) of Peru and Bolivia. Here, we report 2 new localities in the department of Junín, central Peru, where it was detected in forests dominated by Polylepis canoi, P. rodolfo-vasquezii, and a third undescribed Polylepis species. We conclude that a residential population is the more likely possibility although the possibility of dispersal individuals should also be considered.
\end{abstract}

\section{Key words}

Andean birds; climate change; conservation; endangered species; High Andes; mountain ecosystems; source-sink habitats.

Academic editor: Galo Buitrón-Jurado | Received 6 December 2017 | Accepted 14 April 2018 | Published 4 May 2018

Citation: Quispe-Melgar HR, Navarro Romo WC, Ames-Martínez FN, Camel Paucar VF, Sevillano-Ríos CS (2018) New distribution records of Anairetes alpinus (Carriker, 1933) (Aves, Tyrannidae), a highly specialized and endangered bird of Polylepis forests in Junín, Peru. Check List 14 (3): 499-504. https://doi.org/10.15560/14.3.499

\section{Introduction}

The Ash-breasted Tit-tyrant, Anairetes alpinus (Carriker, 1933) (Aves, Tyrannidae), is a highly specialized bird species that inhabits the Polylepis forests (Rosaceae) of Peru and Bolivia (Fjeldså 1993, Fjeldså 2002, Lloyd 2008a, b, Birdlife International 2018). Given its small geographic range of occurrence and small population size, currently estimated at 150-700 individuals, this species has been categorized as Endangered in the IUCN Red List of threatened species (Birdlife International 2018). Its restricted elevational range $(3,700-4,600 \mathrm{~m})$
(Schulenberg et al. 2007) makes this species particularly vulnerable to various human activities that occur at these elevations, such as heavy grazing, uncontrolled fire, and local changes in land use (Fjeldså and Kessler 2004, Gómez 2009). These activities have been postulated as the main drivers of the ongoing habitat loss and degradation (Renison et al. 2002, Purcell and Brelsford 2004, Renison et al. 2010, Sylvester et al. 2017), simultaneously preventing the natural regeneration of Polylepis (Gómez 2009, Morales 2017, Morales et al. 2018).

In Peru and Bolivia, roughly 3 main areas where this species occurs have been identified (Fig. 1). The 


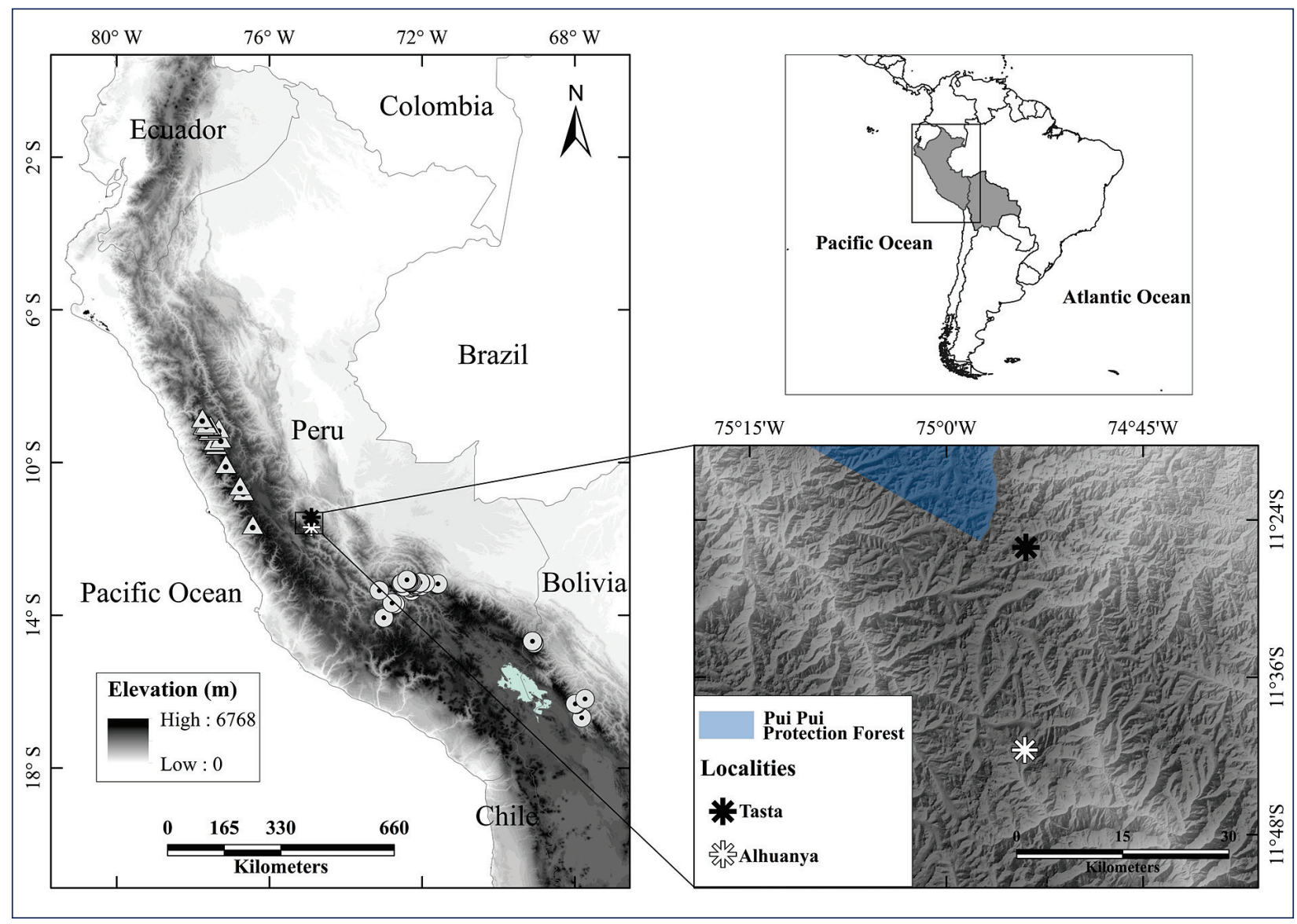

Figure 1. Records of the presence of Anairetes alpinus. Triangles indicate the presence of the A. alpinus alpinus while the circles indicate $A$. alpinus bolivianus. Records were taken from the eBird database (eBird 2017), GBIF (GBIF Secretariat 2017) and Greeney (2013). The white (Alhuanya) and black (Tasta) asterisks indicate the new records in department of Junín, central Peru.

northernmost population occurs along the high Andes of northern Peru, mainly in the mountain chains of the Cordilleras Blanca, Huayhuash, La Viuda, Central, and Chonta (Sevillano-Ríos et al. in press). There, A. a. alpinus inhabits small, high-elevation Polylepis patches of apparently high-quality habitat (Sevillano-Ríos and Rodewald 2017), where several resident groups of up to approximately 10 individuals can easily be observed (Sevillano-Ríos 2016, CSSR per. obs.). In southern Peru, in the departments of Abancay and Cuzco, A. a. bolivianus occurs along the Cordilleras Vilcabamba and Vilcanota (Lloyd 2008 a, b, Lloyd and Marsden 2008). Here, some of the principal populations are estimated to be about 20-30 individuals (Engblom et al. 2002), although the densities seem to be low (ca 4.9 individuals $/ \mathrm{km}^{2}$ ) (Lloyd 2008a). Finally, the southernmost populations occur mainly in the Cordilleras Real and Apolobamba, Bolivia, where A. a. bolivianus also occurs; it was estimated to be roughly 150 individuals after visiting 5 different localities (Gómez 2009).

These 3 main areas maintain the core populations of the A. alpinus, where different conservation strategies have been proposed to save this and many other threatened birds of the Polylepis forests (BirdLife International 2018). However, areas in between these core populations are poorly studied. Our discovery of new localities is important, not only for a better understanding of the distributional patterns of this species but to understand its ecology and to locate new areas for its conservation. We report 2 new localities in the department of Junín, central Peru.

\section{Methods}

To assess the diversity of high Andean birds in central Peru, fieldwork was conducted between May 2016 and October 2017 at 23 locations (17 in the department of Junín, 3 in Huancavelica, and 3 in Lima). At all these sites, typical high-Andean ecosystems (3,450-4,550 m above sea level) such as Polylepis forest, mixed shrublands, and puna pastures were surveyed. Each site was visited for 3 or 4 consecutive days twice over 2 years. Point counts of 10 minutes duration were made, separated by a minimum distance of $150 \mathrm{~m}$. These took place in the mornings (06:00-12:00) and afternoons (14:00-18:00) and were complemented by mist-netting efforts (12 $\mathrm{m} ; n$ $=2$ ) placed in open areas within the forests to passively capture passing birds.

\section{Results}

New records. Peru, Junín, province of Concepción, dis-

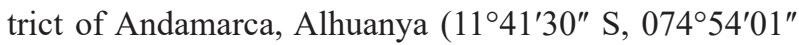
W, $4100 \mathrm{~m}$ elev.), observ. by H.R.Quispe-Melgar, 13 

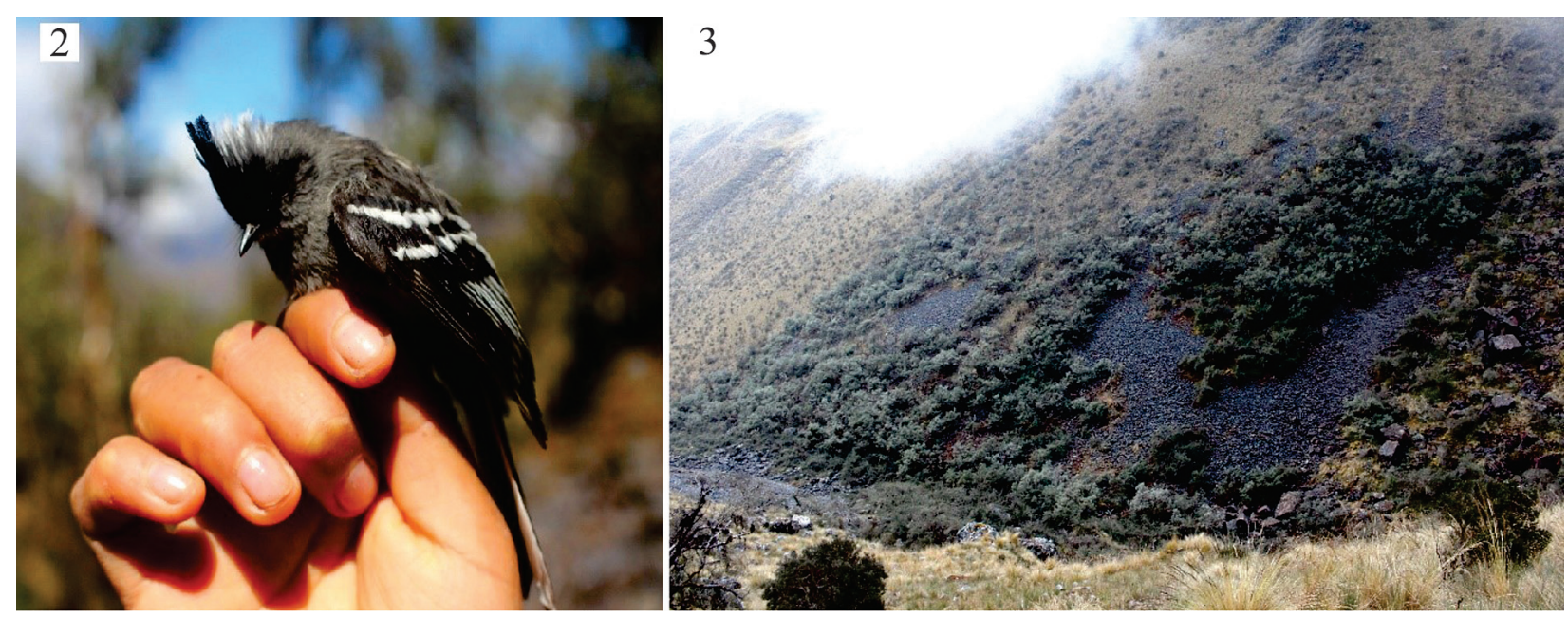

Figures 2, 3. First record of Anairetes alpinus in Junín, Peru. 2. Specimen captured in Alhuanya. 3. Forest of Polylepis rodolfo-vasquezii and Polylepis sp. where 1 individual was captured. Human impact is observed by felling, burning and livestock, also rocky sliding. (Photographs by HRQM.)

July 2017, 11:15 h, 1 adult captured (Figs 2, 3). Peru, Junín, province of Satipo, district of Pampa Hermosa, Tasta ( $11^{\circ} 26^{\prime} 05^{\prime \prime} \mathrm{S}, 074^{\circ} 53^{\prime} 56^{\prime \prime} \mathrm{W} ; 3,900 \mathrm{~m}$ elev.) observ. by H.R. Quispe-Melgar, 21 September 2017, 07:00 h, 2 adults (Figs 4, 5).

The specimen of A. alpinus captured in Alhuanya was measured (Table 1) and photographed (Figs 2, 3). The bird was identified as an adult of undistinguished sex, with no signals of molting in the wings although other parts of the body were not assessed. On the wings, lice were detected. The bird was captured in a mist net located

Table 1. Measure of Anairetes alpinus captured in Alhuanya. Measurements were taken following Baldwin et al. (1931).

\begin{tabular}{lc}
\hline Measurements (mm) & \\
\hline Bill width (At nostrils) & 3.0 \\
Bill length (nostrils to tip) & 8.2 \\
Wing lenght & 68.5 \\
Tail lenght & 68.8 \\
Tarsus lenght & 20.1 \\
Total length (bill tip to tail) & 115.2 \\
\hline
\end{tabular}

in an open area inside a 1.5 ha mixed patch dominated by Polylepis rodolfo-vasquezii and another undescribed species of Polylepis. The nearby area was characterized by open and shrubby vegetation composed by Buddleja, Gynoxys, Miconia, and some single Polylepis stands surrounded by puna pastures. Signs of human activities where evident all over the area.

The second observation was in a 5 ha patch dominated by Polylepis canoi (Figs 4, 5). On this occasion, 2 individuals were seen together, moving from branch to branch through the Polylepis canopy. The humidity seemed to be higher in this forest compared to Alhuanya, although the vegetation appeared similar, and we also observed additional species such as Escallonia, Hesperomeles, and Clethra, with few signs of human activity.

Although intensive searching was conducted in both places, including the use of playbacks during the following days, we failed to record the bird again. The 2 localities were approximately $28 \mathrm{~km}$ apart.

Identification. All captured/observed birds species were

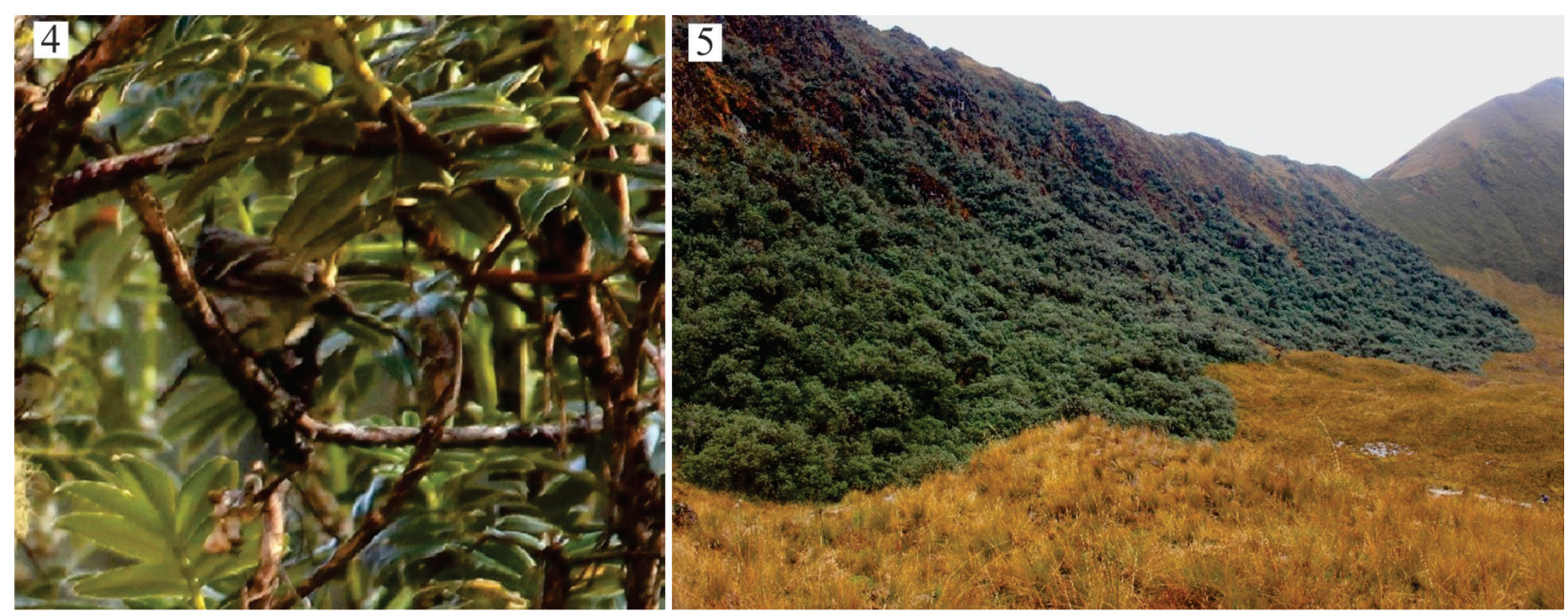

Figures 4, 5. The second record of Anairetes alpinus in Junín, Peru. 4. Sighting in Tasta. 5. The forest was dominated by Polylepis canoi and the presence of human activities was less than at Alhuanya. (Photographs by HRQM.) 
identified based on Schulenberg et al. (2007) and corroborated with the database of the Cornell Macaulay Library (Macaulay Library at the Cornell Lab 2018) and Avibase (Avibase 2017). Within the genus Anairetes there are 6 species (DuBay and Witt 2012, SACC 2017). Anairetes alpinus is distinguished from its congeners by having a plain ashy color pattern, 2 pronounced white wing bars, absence of stripes on the chest, a white patch on the belly, and 3 outer rectrices with white coloration (Carriker 1933). However, the identification of the subspecies $A$. $a$. alpinus and A. a. bolivianus is more complicated, given that an in-hand comparison of specimens seems to be required to observe the degree of black coloration on the crown and the white central belly, among other distinguishing characteristics (Carriker 1933, 1935, Fitzpatrick and Sharpe 2017).

\section{Discussion}

Prior to our new records from Junín, the presence of this species in this region was unknown. These records, therefore, are important for understanding the distributional pattern of this endangered species. These records might represent non-resident individuals that were dispersing between known main populations or they might serve as evidence of a resident population in Junín that was previously overlooked.

The first hypothesis is supported by the fact that in places where this species is resident, such as Ancash, Cusco, and La Paz, it tends to be locally common and easily detected (Lloyd 2008a, Gómez 2009, SevillanoRíos and Rodewald 2017). For example, in the Cordillera Blanca, A. alpinus occupies the same Polylepis forest patches year after year, where a few groups of normally 4 or 5 individuals are often observed foraging only in Polylepis trees. These observations suggest a high degree of specialization and territoriality, which explain why they easily respond to playback through vocalizing from the top of the trees, fluttering, and short display flights (Servat 2006, CSSR unpublished data). In Junín, however, though we used playback and searched intensively throughout the forest, we failed to detect the species more than once. Additionally, no evidence (e.g. brood or individuals carrying nest materials) suggests a breeding population in these areas, which opens the possibility that these records are non-resident individuals dispersing between main populations (but from where?).

If we observe the spatial distribution of the new records with respect to the known main populations, we see that they are located between the A. a. alpinus (northwest) and A. a. bolivianus (southeast) resident populations (Figure 1). The closest of these main populations are approximately $168 \mathrm{~km}$ west in Carampoma, department of Lima (11 $\left.37^{\prime} 34^{\prime \prime} \mathrm{S}, 076^{\circ} 26^{\prime} 09^{\prime \prime} \mathrm{W}\right)$ and about $290 \mathrm{~km}$ northwest in Aquia, department of Ancash $\left(10^{\circ} 02^{\prime} 09^{\prime \prime} \mathrm{S}\right.$, $\left.077^{\circ} 08^{\prime} 38^{\prime \prime} \mathrm{W}\right)$; both belong to the subspecies $A$. a. alpinus. On the other hand, the closest populations of $A$. $a$. bolivianus are at approximately $265 \mathrm{~km}$ southeast in the
Cordillera Vilcabamba, department of Cuzco (13 $21^{\prime} 03^{\prime \prime}$ $\left.\mathrm{S}, 073^{\circ} 07^{\prime} 12^{\prime \prime} \mathrm{W}\right)$. In general, the regions of Lima, Ancash, and Cuzco have a high concentration of Polylepis forests where the populations of $A$. alpinus may be functioning as "sources" given that, at least, they look like stable populations. The areas in between, though not devoid of Polylepis patches and other vegetation communities that include Gynoxys, may only be suitable for the dispersal of $A$. alpinus but unsuitable for a stable population. Certainly, A. alpinus does forage on other plant species like Gynoxys, Baccharis, and Buddleia, among others (Servat 2006, Gomez 2009), and it appears that the degree of specialization to Polylepis decreases with latitude (Servat 2006, CSSR unpublished data). Although these records might be non-residential individuals dispersing between main populations; the large distance in between, their small population sizes, and the high specialization to Polylepis makes this claim dubious.

On the other hand, the possibility that the new records are from a small, previously unreported population is supported in that we detected A. alpinus only at 2 of the 23 sites. This agrees with this species' inherent pattern of rarity observed in other areas such as Ancash, Cusco, and La Paz (Lloyd 2008a, Gómez 2009, Sevillano-Ríos and Rodewald 2017) and might suggest that it was overlooked because of its rarity. Indeed, studies in Ancash, where this species is known to occur, failed to detect them even after intensive survey effort (Sevillano-Ríos et al. 2011, Servat 2006). In Ancash, A. alpinus mainly occurs in very high elevation Polylepis forests (> 4,200 m) while those surveys were placed on the extensive Polylepis forests that occur at lower elevations (Sevillano-Ríos and Rodewald 2017). Unpublished observations suggest that interspecific competition between A. alpinus and Anairetes nigrocristatus Taczanowski, 1884 (Black-crested Tittyrant) could be responsible for this pattern in Ancash. In Junín, these 2 species also occur (Schulenberg et al. 2007, Sullivan et al. 2009, CSSR unp. Obs.) and it is reasonable to think that these records correspond to a resident population of $A$. alpinus that might inhabit higher elevations that we had not surveyed. Moreover, while the record of 1 individual could be used to support the dispersal hypothesis, it seems unlikely that 3 individuals were dispersing through a whole new area almost at the same time. This is especially unlikely considering their high degree of specialization and territoriality.

In the absence of genetic material, dispersal data, or an adequate plumage comparison to subspecies (Figs 6-8), it is impossible to know if these individuals are dispersing or residents. Still, we believe that a resident population is more likely, although the possibility of a dispersal corridor should also be considered. If these records correspond to an undescribed resident population, only further exploration or records could confirm this. Nevertheless, if we consider the possibility that Junín it is part of a biological corridor, the importance of these areas in between would be as sink habitats. That could function as corridors that connect and prevent populations from 

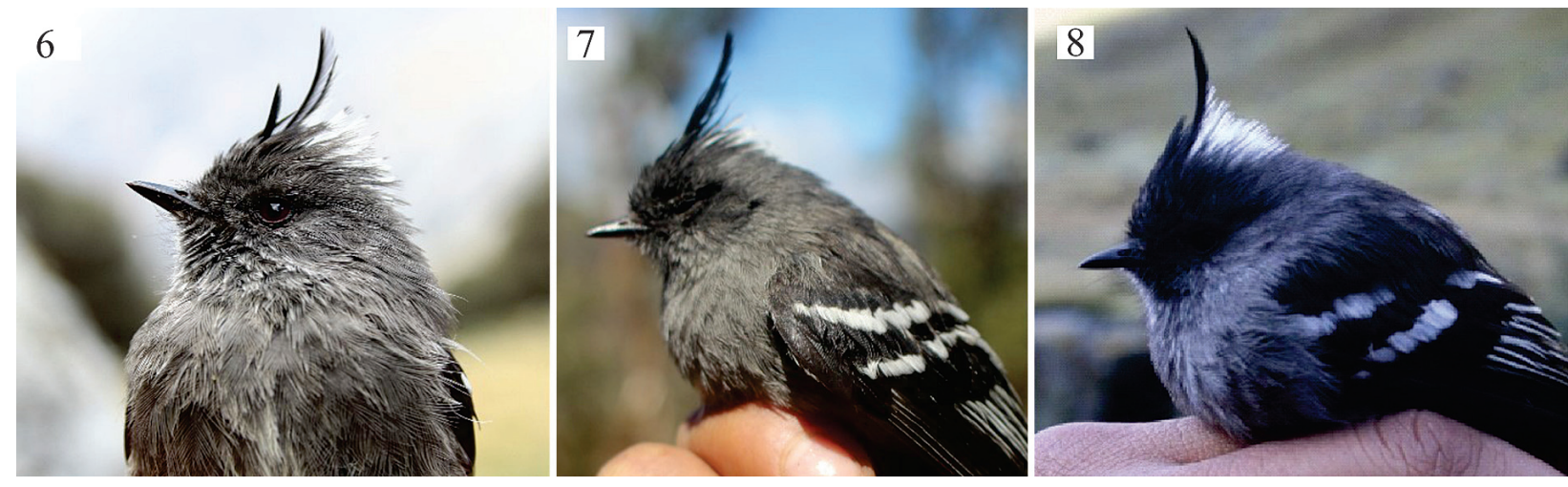

Figures 6-8. The different plumage forms of Anairetes alpinus are difficult to distinguish just from photos due to differences in setting and light conditions. 6. A. alpinus alpinus from Ancash. (Photograph by CSSR.) 7. A. alpinus from Junín. (Photograph by HRQM.) 8. A. alpinus bolivianus from Puno (Photograph by Willy Maldonado).

inbreeding depression, which is important if the objective is the conservation of endangered species that live in highly fragmented habitats such as Polylepis forests (Bennett 1999, Christie and Knowles 2015). Another area that we should consider for further studies (because it could serve as a corridor between Cuzco and La Paz), is the one formed by the Cordillera Carabaya, right next to Cordillera Apolobamba, along the eastern Andean slope between Peru and Bolivia. This suggestion is based on the record of one isolated individual of $A$. alpinus in Sandia (Maldonado pers. comm.). Finally, studies that integrate dispersion, genetic, and population demography data at a regional scale would help us to understand more about the ecology of this little-known species of threatened birds and improve current conservation efforts.

\section{Acknowledgements}

We thank the Consejo Nacional de Ciencia, Tecnología e Innovación Tecnológica for funding Project No. 149-2015 FONDECYT-DE and the Servicio Nacional Forestal y de Fauna Silvestre, that through General Management Resolution No. 037-2017-SERFOR/DGGSPFFS approved our research outside of protected natural areas. We also thank Willy Maldonado for providing us with the photograph of A. alpinus bolivianus and the 3 anonymous reviewers that helped improve the manuscript with their comments and suggestions. Finally, our gratitude goes to Sharon-Rose Alonzo and Darin MacNeil for their help with the English revision.

\section{Authors' Contributions}

HRQM, WCNR, FNAM and VFCP collected the field data, HRQM and CSSR wrote the manuscript.

\section{References}

Avibase (2017) https://avibase.bsc-eoc.org/avibase.jsp?lang=EN. Accessed on: 2017-9-25

Baldwin SP, Oberholser HC, Worley LG (1931) Measurements of birds. Scientific Publications of the Cleveland Museum of Natural History 2: 1-165. https://doi.org/10.5962/bhl.title.60247
Bennett AF (1999) Linkages in the landscape: the role of corridors and connectivity in wildlife conservation (No. 1). IUCN, Gland, Switzerland/Cambridge, UK, $254 \mathrm{pp}$.

BirdLife International (2018) Species Factsheet: Anairetes alpinus. http://www.birdlife.org. Accessed on: 2018-2-7.

Carriker MAJ (1933) Descriptions of new birds from Peru, with notes on other little-known species. Proceedings of the Academy of Natural Sciences of Philadelphia 85: 1-38.

Carriker MAJ (1935) Descriptions of new birds from Bolivia, with notes on other little-known species. Proceedings of the Academy of Natural Sciences of Philadelphia 87: 313-341.

Christie MR, Knowles LL (2015) Habitat corridors facilitate genetic resilience irrespective of species dispersal abilities or population sizes. Evolutionary Applications 8 (5): 454-463. https://doi. org/10.1111/eva.12255

DuBay SG, Witt CC (2012) An improved phylogeny of the Andean tittyrants (Aves, Tyrannidae): more characters trump sophisticated analyses. Molecular Phylogenetics and Evolution 64: 285-296. https://doi.org/10.1016/j.ympev.2012.04.002

eBird (2017) eBird: An Online Database of Bird Distribution and Abundance. eBird, Ithaca, New York. http://www.ebird.org. Accessed on: 2017-11-15.

Engblom G, Aucca C, Ferro G, Samochuallpa E, Palomino W (2002) The conservation of Polylepis-adapted birds at Abra Malaga, Cuzco, Peru. Cotinga 17: 56-59.

Fitzpatrick J, Sharpe CJ (2017) Ash-breasted Tit-tyrant (Anairetes alpinus). In: del Hoyo J, Elliott A, Sargatal J, Christie DA, de Juana E (Eds). Handbook of the Birds of the World Alive. Lynx Edicions, Barcelona. https://www.hbw.com/node/57174. Accessed on: 2017-12-1.

Fjeldså J (1993) The avifauna of the Polylepis woodlands of the Andean highlands: The efficiency of basing conservation priorities on patterns of endemism. Bird Conservation International 3 (1): 37-55. https://doi.org/10.1017/S0959270900000770

Fjeldså J (2002) Key areas for conserving the avifauna of Polylepis forests. Ecotropica 8: 125-131.

Fjeldså J, Kessler M (2004) Conservación de la biodiversidad de los bosques de Polylepis de las tierras altas de Bolivia. Una contribución al manejo sustentable en los Andes. DIVA Technical Report 11. Editorial FAN, Santa Cruz de la Sierra, Bolivia, 214 pp. GBIF Secretariat (2017) GBIF Backbone Taxonomy. Checklist Dataset. https://doi.org/10.15468/39omei. Accessed via GBIF.org on: 2017-11-15.

Gómez IM (2009) Libro Rojo de la fauna silvestre de vertebrados de Bolivia. In: Aguirre LF, Aguayo R, Balderrama JA, Cortez C, Tarifa T, Rocha OO (Eds). Libro Rojo de la fauna silvestre de vertebrados de Bolivia (pp. 353-354). Ministerio del Medio Ambiente y Agua, La Paz, Bolivia, 353-354.

Greeney HF (2013) The nest of the Ash-breasted Tit-tyrant (Anairetes alpinus). Ornitología Colombiana 13: 74-78. 
Lloyd H (2008a) Abundance and patterns of rarity of Polylepis birds in the Cordillera Vilcanota southern Peru: implications for habitat management strategies. Bird Conservation International 18: 164-180. https://doi.org/10.1017/S0959270908000166

Lloyd H (2008b) Foraging ecology of high Andean insectivorous birds in remnant Polylepis forest patches. The Wilson Bulletin of Ornithology 120: 531-544. https://doi.org/10.1676/07-059.1

Lloyd H, Marsden SJ (2008) Bird community variation across Polylepis woodland fragments and matrix habitats: implications for biodiversity conservation within a high Andean landscape. Biodiversity and Conservation 17: 2645-2660. https://doi.org/10.1007/ s10531-008-9343-2

Macaulay Library at the Cornell Lab (2018) https://www.macaulay library.org/. Accessed on: 2017-9-25.

Morales LV, Sevillano-Ríos CS, Fick S and Young T (2018) Differential seedling regeneration patterns across forest-grassland ecotones in two tropical treeline species (Polylepis spp.). Austral Ecology. https://doi.org/10.1111/aec.12588

Morales L (2017) Polylepis regeneration and the potential for fores expansion in the Peruvian Andes: The influence of cattle and environmental conditions. PhD thesis, University of California, Davis, California, 105 pp.

Purcell J, Brelsford A (2004) Reassessing the causes of decline of Polylepis, a tropical subalpine forest. Ecotropica 10: 155-158.

Renison D, Cingolani AM, Suarez R (2002) Effects of fire on a Polylepis australis (Rosaceae) woodland in the mountains of Cordoba, Argentina. Revista Chilena de Historia Natural 75 (4): 719-727.

Renison D, Hensen I, Suarez R, Cingolani AM, Marcora P, Giorgis MA (2010) Soil conservation in Polylepis mountain forests of Central
Argentina: is livestock reducing our natural capital? Austral Ecology 35 (4): 435-443.

SACC (2017) http://www.museum.lsu.edu/ Remsen/SACCBaseline. htm. Accessed on: 2017-10-15.

Schulenberg TS, Stotz DF, Lane DF, O’Neill JP, Parker TA III (2007) Birds of Peru. Princeton, New Jersey, 664 pp.

Servat GP (2006) The role of local and regional factors in the foraging ecology of birds associated with Polylepis woodlands. PhD thesis, University of Missouri-St. Louis, St. Louis Missouri, 164 pp.

Sevillano-Ríos CS (2016) Diversity ecology and conservation of bird communities of Polylepis woodlands in the northern Andes of Peru. Master's Thesis, Cornell University, Ithaca, New York, 149 pp. http://doi.org/10.7298/x45d8psk

Sevillano-Ríos CS, Rodewald AD (2017) Avian community structure and habitat use of Polylepis forests along an elevation gradient. PeerJ 5: e3220. https://doi.org/10.7717/peerj.3220

Sevillano-Ríos CS, Rodewald AD, Morales L (in press) Ecología y conservación de las aves asociadas a Polylepis: ¿qué sabemos de esta comunidad cada vez más vulnerable? Ecología Austral.

Sullivan BL, Wood CL, Iliff MJ, Bonney RE, Fink D and Kelling S (2009) eBird: a citizen-based bird observation network in the biological sciences. Biological Conservation 142 (10): 2282-2292. https://doi.org/10.1016/j.biocon.2009.05.006

Sylvester SP, Heitkamp F, Sylvester MDPV, Jungkunst HF, Sipman HJM, Toivonen JM, Gonzales CAI, Ospina JC, Kessler M (2017) Relict high-Andean ecosystems challenge our concepts of naturalness and human impact. Scientific Reports 7 (1): 1-13. https://doi.org/10.1038/s41598-017-03500-7 